\title{
Migration of phthalates and 2,6-diisopropylnaphthalene from cellulose food packaging
}

\author{
Leda Coltro $^{1 *}$ (i), Elisabete Segantini Saron ${ }^{1}$ (D), Thiago Ivan Pessoa ${ }^{2}$ (i), Julia Morandi ${ }^{2}$ (D) and \\ Bruna Santos Silva ${ }^{1}$
}

\author{
${ }^{1}$ Centro de Tecnologia de Embalagem, Instituto de Tecnologia de Alimentos - ITAL, Campinas, SP, Brasil \\ ${ }^{2}$ Instituto de Química, Universidade Estadual de Campinas - UNICAMP, Campinas, SP, Brasil \\ *ledacolt@ital.sp.gov.br
}

\begin{abstract}
Recycling systems are unable to remove efficiently all potential contaminants acquired along the recycling chain. Therefore, contaminants may potentially exist in recycled food packaging. The safety of recycled cellulose food-contact materials depends on the toxicity and the ability of post-consumer contaminants to be absorbed by recycled fibers released by the packaging and ultimately absorbed by the food. Furthermore, the migration of different contaminants is related to their levels of contamination, structures and chemical affinity with cellulose fibers. In this study, twenty samples of cellulose packages available in the Brazilian market were evaluated regarding migration of phthalates (dibutyl phthalate - DBP, diisobutyl phthalate - DIBP and bis(2-ethylhexyl) phthalate-DEHP) and 2,6-diisopropylnaphthalene - DIPN into fatty food simulant using GC-FID. Fifty percent of the cellulose packaging samples showed no migration of DIPN or of any phthalates evaluated, whereas $20 \%$ showed migration of DIBP, $15 \%$ migration of DBP and $40 \%$ migration of DEHP.
\end{abstract}

Keywords: cellulose packaging, contaminants, phthalates, migration, recycled fibers.

How to cite: Coltro, L., Saron, E. S., Pessoa, T. I., Morandi, J., \& Silva, B. S. (2021). Migration of phthalates and 2 , 6-diisopropylnaphthalene from cellulose food packaging. Polímeros: Ciência e Tecnologia, 31(2), e2021017. https:// doi.org/10.1590/0104-1428.02321

\section{Introduction}

Packaging recycling is critical to circular economy. Recycling cellulose packaging (paper, cardboard and corrugated paperboard) is a traditional practice in Brazil. Since the 1990 s, recycling rates have ranged from $70 \%$ to $80 \%$. In 2019 , approx. $85 \%$ of the total volume of cellulose packaging consumed in the country was recycled ${ }^{[1]}$.

Due to the use of recycled packaging to manufacture food contact packaging, strict regulation of materials is required to prevent risks to food safety, since recycling systems are unable to eliminate all potential contaminants efficiently.

The fibers of recycled paper and cardboard may have several contaminants due to: i) recycling of non-food grade paper and cardboard; ii) recycling of printed materials, adhesives or coatings of paper and cardboard still remaining after recycling; iii) additives used in recycling; iv) residues in the paper and cardboard remaining after these materials have been used; and v) degradation products and chemical impurities introduced in the different stages of the chain ${ }^{[2]}$.

Therefore, the potential presence of contaminants in the recycled packaging exists. Such contaminants may migrate into food, thus resulting in risks to consumers ${ }^{[3-7]}$. The safety of recycled cellulose materials for use in food contact packaging depends on the toxicity and the ability of post-consumer contaminants to be absorbed by recycled fibers, then released by the packaging and ultimately absorbed by the food. Besides, migration of different contaminants

is related to their levels of contamination, structures and chemical affinity with cellulose fibers.

According to EU Regulation (EC) no. 1935/2004 ${ }^{[8]}$, any materials intended to come into direct or indirect contact with food should not transfer substances into food in quantities which could endanger human health, cause unacceptable change in food composition or bring about deterioration in its organoleptic characteristics. Therefore, with the use of recycled paper and cardboard in food contact materials (FCM) a broader range of testing is recommended to ensure consumer health. The European Food Safety Authority - EFSA established a safe level - a group Tolerable Daily Intake (TDI) for dibutyl phthalate - DBP and bis(2-ethylhexyl) phthalate-DEHP of 0.01 and $0.05 \mathrm{mg}$ per kilogram of body weight $\left(\mathrm{mg} \mathrm{kg}^{-1} \mathrm{bw}\right)$ per day, taking into account their effects on the reproductive system. Since the structure of diisobutyl phthalate - DIBP is comparable to DBP, its TDI was also set as $0.01 \mathrm{mg} \mathrm{kg}^{-1}$ bw per day. TDI is an estimate of the amount of a substance that a person can ingest daily during his/her lifetime without any significant risks to health ${ }^{[9]}$.

In 2020, the European Committee for Food Contact Materials and Articles submitted a technical guide on materials and articles made of food-contact paper and cardboard to public consultation, as there are no specific requirements for these materials in Europe; however, they must comply with the national regulations of the country 
where the products are marketed. This technical guide is based on the regulations for paper and cardboard packaging from Germany, France, Italy and the Netherlands; it sets forth the following specific migration limits - SML: sum of $0.3 \mathrm{mg} \mathrm{kg}^{-1}$ for DBP and DIBP; $1.5 \mathrm{mg} \mathrm{kg}^{-1}$ for DEHP and absence of DIPN ${ }^{[2]}$.

To ensure food safety, packaging in Brazil must comply with the regulations agreed among the MERCOSUR countries (Southern Common Market), according to Resolution RDC no. 88 , of June $29^{\text {th }}, 2016$, issued by the Brazilian National Health Surveillance Agency (Anvisa) of the Brazilian Ministry of Health ${ }^{[10]}$. This Resolution includes a positive list of components for materials, packages and cellulose equipment intended to come into contact with food, specifying maximum SML for various substances, including inorganic contaminants, when the material includes recycled fibers in its production. The SML for substances evaluated in this study are the same as those adopted by the EU, i.e.: $0.3 \mathrm{mg} \mathrm{kg}^{-1}$ for DBP; $0.3 \mathrm{mg} \mathrm{kg}^{-1}$ for DIBP - taking into account that the sum of DBP and DIBP must not exceed $0.3 \mathrm{mg} \mathrm{kg}^{-1}$; $1.5 \mathrm{mg} \mathrm{kg}^{-1}$ for DEHP and it must be non-detectable for 2,6-diisopropylnaphthalene-DIPN. This Resolution does not apply to secondary packaging made of paper or cardboard, as long as it is ensured that they do not come into contact with food, do not interfere with food integrity and do not transfer unhealthy substances.

Phthalates are potential contaminants that can migrate from cellulose packaging into food. Some studies have shown that phthalates cause genetic changes in mice, and DEHP is an endocrine disruptor that can trigger toxic and adverse effects, particularly in animal or human tissues and organs, such as the pituitary gland, liver or testicles ${ }^{[11-13]}$. However, these additives are often unintentionally incorporated due to the possibility and permission to use recycled pulps ${ }^{[14]}$. They are a group of organic lipophilic chemicals used primarily as plasticizers to increase flexibility of polymer products and may be found in printing inks, lacquers and adhesives of such packages. DBP, DIBP and DEHP are some of these phthalates that can migrate into food ${ }^{[5]}$. Contamination may take place when the unprinted and the printed surfaces of the packaging touch when the cellulose material is wound or stacked and stored. As a consequence, printing components can migrate into food. This is known as set-off effect ${ }^{[15,16]}$.

DIPN is mostly found in packaging that has been produced from recycled office papers, since it is used as solvent for dyes in carbonless copy paper in substitution to polychlorinated biphenyls. It can migrate into food through direct contact or even through gaseous transpor ${ }^{[5,17]}$. After several analyses at different concentrations, Zhang, Noonan and Begley observed that at concentrations higher than $20 \mathrm{mg} \mathrm{kg}^{-1}$ DIPN migration into food products is detected ${ }^{[3]}$. According to estimation made by Coltro and Machado based on analyses of samples contaminated with different levels of DIPN, $12 \mathrm{mg} \mathrm{kg}^{-1}$ is the maximum concentration of DIPN in cellulose packaging to reach the specific migration limit of $0.01 \mathrm{mg} \mathrm{kg}^{-1}$ or to be detected ${ }^{[18]}$.

Geueke and Muncke conducted a systematic literature review of studies that detected phthalate migration into food or food simulants ${ }^{[4]}$. Among the studies listed by Geueke and Muncke there is a study, from 2012, on migration of 33 food packaging items (11 materials) into various food simulants (water, $3 \%$ acetic acid or $15 \%$ ethanol) in which the authors identified migration of DEHP between limit of detection - LOD and $17.7 \mu \mathrm{g} \mathrm{L}^{-1}(55 \%$ detection frequency), DBP between LOD and $1.95 \mu \mathrm{g} \mathrm{L}^{-1}$ (33\% detection frequency) and benzyl butyl phthalate - BBP between LOD and $0.355 \mu \mathrm{g} \mathrm{L}-1$ (36\% detection frequency). Another study, from 2013, on 17 samples of recycled paper and cardboard, the authors quantified DEHP migration in 12 samples, with values between 0.97 and $66.3 \mathrm{mg} \mathrm{kg}^{-1}$. In a study from 2016, conducted with 19 paper cups, the authors analyzed extraction and migration of phthalates into different food simulants. The results showed that all samples contained DEHP (from 0.45 to $58.6 \mathrm{mg} \mathrm{kg}^{-1}$ ) and DBP (from 0.07 to $3.14 \mathrm{mg} \mathrm{kg}^{-1}$ ), while BBP was measured in two samples. DBP migrated into $20 \%$ and $50 \%$ ethanol, $4 \%$ acetic acid and $n$-heptane, but not into water and DEHP migrated only into $\mathrm{n}$-heptane.

Graiño et al. analyzed potential migrants in paper-based candy wrappers ${ }^{[19]}$. The authors analyzed seven samples of paper-based candy wrappers and two samples of popcorn paper packaging. Among the 28 compounds identified in the packaging samples, four phthalates were found: diethyl phthalate - DEP (eight samples), DIBP (eight samples), BBP (three samples) and DEHP (all samples).

Therefore, this study aims to assess migration of DIPN and DBP, DIBP and DEHP phthalates from cellulose food packaging commonly available in the Brazilian market into fatty food simulant (n-heptane) to assess the exposure of Brazilians to phthalates and DIPN.

\section{Materials and Methods}

\subsection{Reagents}

The following reagents were used in this study: 2,6 - diisopropylnaphthalene - DIPN, CAS number 24157-81-1 (Sigma-Aldrich, 99\%); dibutyl phthalate-DBP, CAS number 84-74-2 (Sigma-Aldrich, 99\%); diisobutyl phthalate - DIBP, CAS number 84-69-5 (Sigma-Aldrich, 99\%); bis(2-ethylhexyl) phthalate - DEHP, CAS number 117-81-7 (Sigma-Aldrich, 99\%); benzyl butyl phthalate BBP, CAS number 85-68-n (Sigma-Aldrich, 98\%), used as internal standard; and n-heptane p.a. (Synth), used as fatty food simulant.

\subsection{Packaging samples}

Several types of cellulose packaging (paper and cardboard used as primary and/or secondary dry food packaging were purchased in the retail market in Campinas, São Paulo, Brazil between 2016 and 2019. The packages are listed in Table 1. The tests of specific migration from the packages into fatty food simulant were carried out both with primary (direct contact with food) and secondary packages.

The cellulose food packages were characterized as to grammage and thickness. The tests were conducted at $23^{\circ} \mathrm{C} \pm 1{ }^{\circ} \mathrm{C}$ and $50 \% \pm 2 \%$ relative humidity after conditioning the samples under these same conditions for at least 48 hours.

The thickness of paper and cardboard packages was measured using mechanical scanning according 
Table 1. Cellulose food packages evaluated.

\begin{tabular}{|c|c|c|c|c|}
\hline Sample code & Description & Type of packaging/paper & $\begin{array}{c}\text { Grammage } \\
\left(\mathrm{g} \mathrm{m}^{-2}\right)^{*}\end{array}$ & $\begin{array}{c}\text { Thickness } \\
(\mu \mathrm{m})^{* *}\end{array}$ \\
\hline $1-p$ & Paper package of wheat flour A - white, printed & Primary & $82 \pm 2$ & $84 \pm 4$ \\
\hline $2-p$ & Paper package of wheat flour B - white, printed & Primary & $82 \pm 1$ & $92 \pm 6$ \\
\hline $3-\mathrm{p}$ & Paper package of wheat flour $\mathrm{C}$ - white, printed & Primary & $80 \pm 2$ & $96 \pm 3$ \\
\hline $4-\mathrm{p}$ & Paper package of bread & Primary & $36 \pm 1$ & $60 \pm 0$ \\
\hline $5-p$ & Paper package of powdered chocolate B & Primary & $66 \pm 1$ & $84 \pm 5$ \\
\hline $6-p$ & Paper packaging of cornstarch-white & Primary & $56 \pm 2$ & $82 \pm 2$ \\
\hline $7-\mathrm{c}$ & Cardboard of powdered chocolate A - printed & Secondary & $263 \pm 2$ & $425 \pm 5$ \\
\hline $8-\mathrm{c}$ & Cardboard of powdered chocolate B - printed & Secondary & $263 \pm 10$ & $363 \pm 15$ \\
\hline $9-\mathrm{c}$ & Cornstarch cardboard - printed & Secondary & $236 \pm 2$ & $330 \pm 2$ \\
\hline $10-\mathrm{c}$ & Cookie cardboard - printed & Secondary & $255 \pm 3$ & $346 \pm 5$ \\
\hline $11-\mathrm{c}$ & Cardboard package of oatmeal - printed & Secondary & $234 \pm 3$ & $393 \pm 3$ \\
\hline $12-\mathrm{c}$ & Cardboard package of jelly - produced in 2017 & Secondary $/ 20 \%$ scrap $/ 5 \% \mathrm{PCR}$ & $256 \pm 2$ & n.d. \\
\hline $13-\mathrm{c}$ & Cardboard, white on both sides - produced in Nov. 2016 & Secondary & $511 \pm 19$ & $1379 \pm 109$ \\
\hline $14-\mathrm{c}$ & Cardboard - produced in Apr. 2018 & Secondary $/ 30 \% \mathrm{PCR}$ & $277 \pm 3$ & $381 \pm 7$ \\
\hline $15-\mathrm{c}$ & Cardboard - produced in Jan. 2019 & Secondary $/ 30 \% \mathrm{PCR}$ & $268 \pm 1$ & $352 \pm 5$ \\
\hline $16-\mathrm{c}$ & Takeaway pizza box (cardboard) & Primary & $272 \pm 2$ & $372 \pm 1$ \\
\hline 17-po & Corrugated paperboard of toast - white & Primary & $148 \pm 4$ & $1599 \pm 60$ \\
\hline 18-po & Takeaway pizza box A (corrugated paperboard) & Primary & $533 \pm 5$ & $1860 \pm 12$ \\
\hline 19-po & Takeaway pizza box B (corrugated paperboard) & Primary & $505 \pm 6$ & $2032 \pm 20$ \\
\hline 20-po & Takeaway pizza box C (corrugated paperboard) & Primary & $412 \pm 13$ & $2720 \pm 170$ \\
\hline
\end{tabular}

*Average \pm Standard Deviation relating to 10 specimens. **Average \pm Standard Deviation relating to 20 measures. PCR $=$ post-consumer recycled fibers; n.d. $=$ non determined.

to international standard ISO $4593^{[20]}$. The thickness of paperboard was determined according to Brazilian standard ABNT NBR ISO 3034 $4^{[21]}$. An external digital indicator with maximum $5.1 \mathrm{~mm}$ (Starret), $0.001 \mathrm{~mm}$ resolution was used. Measurements of the surface of the material were taken at 20 different positions. The mean value is reported in Table 1.

The grammage of the cellulose packages was measured by determining the mass of $5 \times 5 \mathrm{~cm}^{2}$ test specimens according to Brazilian standard NBR NM-ISO 536 ${ }^{[22]}$. A model AE163 (Mettler Toledo) analytical balance with $0.1 \mathrm{mg}$ resolution was used. Measurements were taken from 10 specimens of the material. The mean value is reported in Table 1.

\subsection{Migration tests}

The analysis was carried out in compliance with the requirements of Resolution RDC no. 88/16 ${ }^{[10]}$. Resolution RDC no. 88/16 incorporates into the Brazilian National Legal Framework all specifications, thresholds and requirements laid down in GMC MERCOSUR Resolution no. 40/15 (GMC means MERCOSUR Common Market Group). This Resolution provides different contact conditions for migration tests, i.e. prolonged contact at room temperature, brief contact at room temperature, momentary contact at room temperature, processing temperature and hot filling. In addition, this Resolution establishes four food simulants: ultra-purified water (aqueous foods), $3 \%$ acetic acid (aqueous acidic foods), $10 \%$ ethanol or higher content (alcoholic foods) and $\mathrm{n}$-heptane (fatty foods).

The fatty food simulant (n-heptane) was selected for all samples under review since phthalates have a greater affinity for fatty foods, and this is the worst scenario to study.
Dry foods packed in cellulose packaging, such as those evaluated in this study, are usually kept at room temperature and have a long shelf life. For this reason, cellulose packages/materials were evaluated in this study according to Resolution RDC no. $88 / 16^{[10]}$ contact condition of $20^{\circ} \mathrm{C}$ $\pm 1^{\circ} \mathrm{C} / 30 \mathrm{~min}+1 \mathrm{~min}$.

Nevertheless, in some cases food is placed in the packaging at an elevated temperature and can remain in contact with the packaging for a long time, as the case of takeaway pizza boxes evaluated in this study. For these samples, a different contact condition was adopted according to Resolution RDC no. $88 / 16^{[10]}$, as follows:, $50^{\circ} \mathrm{C} \pm 2^{\circ} \mathrm{C} / 15 \mathrm{~min}+1 \mathrm{~min}$ followed by $20^{\circ} \mathrm{C} \pm 1^{\circ} \mathrm{C} / 30 \mathrm{~min}+1 \mathrm{~min}$.

The specimens were dipped in $\mathrm{n}$-heptane food simulant at a ratio of $0.3 \mathrm{~mL} \mathrm{~cm}^{-2}$ of the analyzed surface, and both faces of the material were considered in the calculations. Twelve square $(5 \mathrm{~cm})$ test pieces of each sample were evaluated, totaling an area of $600 \mathrm{~cm}^{2}$ (considering both sides of the material).

\subsubsection{Overall migration into fatty food simulant}

The quantification of overall migration was based on contact of the samples with extraction solutions for times and temperatures simulating their actual condition of use as described previously (section 2.3). The extract solutions were evaporated, and the residues of overall migration were determined by the difference in weight after the contact employing an analytical balance with $0.01 \mathrm{mg}$ accuracy.

\subsubsection{Specific migration into fatty food simulant}

The cellulose packages/materials were evaluated as to specific migration of DIPN and phthalates employing the method developed in this study and using fatty food simulant 
n-heptane, which is the worst scenario due to the chemical affinity among these substances and the simulant. For printed cardboard samples, the outer (printed) layer was removed and only the inner layer (without printing) was analyzed. Benzyl butyl phthalate (BBP) was employed as internal standard to quantify the plasticizers in the food simulant since this plasticizer is not used in food packaging. After the contact, the extracts were concentrated 25 times employing a rotary evaporator from Fisatom 803, Fisatom 826T vacuum pump, filtered in a $0.45 \mu \mathrm{m}$ polytetrafluoroethylene - PTFE filter and injected into the GC-FID, in triplicate.

\subsection{Chromatographic conditions}

For analysis of migration of target substances from packaging into food simulant, a gas chromatograph with flame ionization detector - GC-FID, from Agilent Technologies 7890A, equipped with an automatic injector Agilent Technologies 7693B was used, operating with a DB-1 capillary column $(30 \mathrm{~m}$ length $\mathrm{x} 0.25 \mathrm{~mm}$ I.D x $0.25 \mu \mathrm{m}$ film thickness). The chromatographic conditions followed the method developed by Coltro et al. ${ }^{[23]}$. The column temperature was set to $60^{\circ} \mathrm{C}$ (hold $1 \mathrm{~min}$ ), a $7^{\circ} \mathrm{C} \mathrm{min}{ }^{-1}$ heating rate from $60^{\circ} \mathrm{C}$ to $100^{\circ} \mathrm{C}$ followed by a $15^{\circ} \mathrm{C} \mathrm{min}{ }^{-1}$ heating rate up to $280^{\circ} \mathrm{C}$ (hold $5 \mathrm{~min}$ ). The total run time was $23.7 \mathrm{~min}$. The injector and detector temperatures were $270^{\circ} \mathrm{C}$ and $300^{\circ} \mathrm{C}$, respectively. Injection volume was $1 \mu \mathrm{L}$. Split mode 35:1.

\subsection{Method validation}

The method was validated according to parameters of selectivity, linearity range, detection limit, quantification limit, recovery, precision and accuracy ${ }^{[24,25]}$.

\subsubsection{Linearity range}

The calibration curves were built in the $1-40 \mathrm{mg} \mathrm{kg}^{-1}$ range (considering a concentration factor of 25 times for solutions of $0.04-1.6 \mathrm{mg} \mathrm{kg}^{-1}$ ) and $2.5 \mathrm{mg} \mathrm{kg}^{-1}$ of BBP (internal standard) taking into account the ratio of the areas (phthalate area / internal standard area) and the respective concentration of phthalate solutions. The coefficients of linear and angular correlation were calculated per the linear regression model.

\subsubsection{Detection Limit (LOD) and Quantification Limit (LOQ)}

Three analytical curves were constructed on different days. With the average peak areas of the compounds under study, it was possible to determine the detection and quantification limits by means of analytical curves using the following equations: $\mathrm{LOQ}=10 *$ linear coefficient error / angular coefficient and LOD $=3.3 *$ linear coefficient error / angular coefficient ${ }^{[24]}$.

\subsubsection{Precision and accuracy}

Two analytical curves were built, being each curve obtained by a different analyst. The intraday repeatability was estimated from the Relative Standard Deviation (RSD) among the replicates of the points of one same curve. The intermediate precision was obtained by calculating the relative standard deviation but considering both analytical curves. The accuracy was assessed via calculation of the relative error (RE), expressed in percentage ${ }^{[26]}$.

\subsubsection{Recovery}

The recovery rate of the tests of migration from packaging into food simulant was obtained via the ratio between the concentrations obtained in the tests and the expected concentration, as represented by the standard solution ${ }^{[26]}$.

\section{Results and Discussion}

\subsection{Validation of the method}

\subsubsection{Specific migration from packaging}

Table 2 shows the validation parameters of the method of specific migration into fatty food simulant for DIPN and the phthalates evaluated. At least five calibration standards with concentrations between $1 \mathrm{mg} \mathrm{kg}^{-1}$ and $40 \mathrm{mg} \mathrm{kg}^{-1}$ were prepared in order to evaluate linearity. This range was selected due to the requirement to ensure linearity at a working range where the specific migration limit - SML - of the phthalates was inserted in the curve (considering a concentration factor of 25 times). All the calibration curves have shown acceptable determination coefficient $\left(r^{2}\right)$ values $(>0.9900)$. LOD and LOQ were lower than SML of the phthalates and DIPN studied and sensitive enough to evaluate possible migration of these substances from commercial samples. The results of precision, calculated in terms of intraday repeatability (one analyst) and intermediate precision (two analysts), were below $10 \%$ for all substances, indicating an acceptable repeatability of the methods. The recovery ranged from $89 \%$ to $104 \%$ and the accuracy ranged from $-11 \%$ to $4 \%$. The Association of Official Analytical Chemists recommends recovery in the range of $75 \%$ to $120 \%$ for concentrations of the order of $1 \mathrm{mg} \mathrm{kg}^{-1[27]}$. The results obtained meet the acceptable ranges and are similar to those obtained by other authors ${ }^{[28,29]}$.

Table 2. Analytical method validation parameters.*

\begin{tabular}{|c|c|c|c|c|}
\hline Parameter $^{1}$ & DIPN & DIBP & DBP & DEHP \\
\hline Working range $\left(\mathrm{mg} \mathrm{kg}^{-1}\right)^{* *}$ & $1-40$ & $1-40$ & $1-40$ & $1-40$ \\
\hline LOD (mg kg $\left.{ }^{-1}\right)$ & 0.007 & 0.005 & 0.005 & 0.006 \\
\hline $\mathrm{LOQ}\left(\mathrm{mg} \mathrm{kg}^{-1}\right)$ & 0.022 & 0.014 & 0.016 & 0.018 \\
\hline Accuracy (\%) & -8.5 to 2.9 & -7.3 to 3.5 & -9.0 to 3.7 & -11.4 to 4.0 \\
\hline Intraday repeatability $(\%)$ & 0.1 to 1.3 & 0.1 to 1.6 & 0.0 to 1.2 & 0.0 to 4.0 \\
\hline Intermediate precision ( $\%)$ & 0.8 to 9.3 & 0.5 to 8.7 & 0.8 à 9.1 & 0.7 to 8.3 \\
\hline Recovery $(\%)$ & 91.5 to 102.9 & 92.7 to 103.5 & 91.0 to 103.7 & 88.6 to 104.0 \\
\hline
\end{tabular}

*Results for triplicates, except for LOD / LOQ (results from seven replicates). **Taking into account a concentration factor of 25 times, which corresponds to a range of $0.04-1.6 \mathrm{mg} \mathrm{kg}^{-1}$ in the sample. $\mathrm{LOD}=$ detection limit; $\mathrm{LOQ}=$ quantification limit. 
As can be seen, the method is suitable to determine specific migration of the phthalates and DIPN under study, since their SML is included in the linearity range and all the other parameters are adequate.

Under the chromatographic conditions adopted, the retention times obtained were $14.00,14.67,15.23$ and $18.54 \mathrm{~min}$ for DIPN, DIBP, DBP and DEHP, respectively. The internal standard evaluated was BBP, with retention time of $17.42 \mathrm{~min}$. Therefore, there was no interference in the analysis of phthalates and DIPN in n-heptane, since there were no overlapping chromatographic peaks.

\subsection{Migration from packages into fatty food simulant}

\subsubsection{Overall migration}

The results for overall migration of all samples that were assessed were below the quantification limit of the method, which corresponds to $2.33 \mathrm{mg} \mathrm{dm}^{-2}$. Resolution RDC no. 88/16 $6^{[10]}$ establishes an overall migration limit of $8.0 \mathrm{mg} \mathrm{dm}^{-2}$, with analytical tolerance of $10 \%$. Therefore, according to this criterion, all packages evaluated are approved for fatty food contact since all packages showed lower overall migration to fatty food simulant than the limit established by legislation. However, these samples must also be evaluated regarding specific migration limits of the substances specified by this Resolution.

\subsubsection{Specific migration}

Results of specific migration - SM of phthalates and DIPN from five samples of cellulose packages purchased in the retail area of Campinas, SP, Brazil showed absence of DIPN migration (non-detected), DIBP migration levels below limit of quantification, DIBP migration up to $0.020 \mathrm{mg}$ $\mathrm{kg}^{-1}$ and DEHP migration up to $0.033 \mathrm{mg} \mathrm{kg}^{-1}{ }^{[30]}$. Therefore, with the aim of examining the exposure of Brazilians to phthalates and DIPN, another fifteen cellulose packages were evaluated in this study.

Table 3 shows the results of SM of phthalates and DIPN from this broader sampling of cellulose packages purchased in the retail area of Campinas, SP, Brazil. The samples showed DIPN migration levels below the detection limit, but sample 20-po showed migration below the quantification limit due to the higher temperature contact conditions. DIPN is the most harmful substance evaluated in this study since the SML is defined according to the toxicity of the substances and SML for DIPN is close to zero (it should not be detected).

Migration levels of phthalates for the contact condition of $20^{\circ} \mathrm{C}$ for $30 \mathrm{~min}$ ranged from below detection limit up to $0.200 \mathrm{mg} \mathrm{kg}^{-1}$ for DIBP, from the limit of detection up to $0.021 \mathrm{mg} \mathrm{kg}^{-1}$ for DBP, and from the limit of quantification up to $0.058 \mathrm{mg} \mathrm{kg}^{-1}$ for DEHP. The specific migration of DIBP was ten times higher than DBP and approximately three times higher than DEHP. Since the structure of DIBP is comparable to that of DBP and they have similar migration rates $^{[18]}$, probably these diverse migration amounts can be due to different degrees of interaction of the contaminants with the cellulosic fibers as well as different concentrations of these substances in the samples.

As can be seen in Figure 1, ten samples (50\%) showed no migration of phthalates or migration below the limit of quantification, three samples (15\%) showed migration of DIBP, three samples (15\%) showed migration of DBP and eight samples (40\%) showed migration of DEHP. Taking into account the packaging material, $33 \%$ of the paper packages, $40 \%$ of the cardboard packages and $75 \%$ of the corrugated cardboard packages showed migration of phthalates.

Table 3. Migration of phthalates and DIPN from cellulose packages into n-heptane, at $20^{\circ} \mathrm{C} / 30 \mathrm{~min}$, in $\mathrm{mg} \mathrm{kg}^{-1 *}$.

\begin{tabular}{|c|c|c|c|c|}
\hline $\begin{array}{c}\text { Sample } \\
\text { code }\end{array}$ & DIPN & DIBP & DBP & DEHP \\
\hline $1-p$ & n.d. ${ }^{1}$ & n.d. & n.d. & $0.036 \pm 0.001$ \\
\hline $2-p$ & n.d. & $<0.014^{2}$ & n.d. & $<0.018^{2}$ \\
\hline $3-p$ & n.d. & n.d. & n.d. & $<0.018^{2}$ \\
\hline 4-p & n.d. & n.d. & n.d. & n.d. \\
\hline $5-p$ & n.d. & $<0.014^{2}$ & $<0.016^{2}$ & $<0.018^{2}$ \\
\hline $6-p$ & n.d. & n.d. & $0.021 \pm 0.010$ & $0.033 \pm 0.007$ \\
\hline 7-c & n.d. & $<0.014^{2}$ & n.d. & $0.040 \pm 0.002$ \\
\hline 8-c & n.d. & n.d. & n.d. & $0.038 \pm 0.001$ \\
\hline 9-c & n.d. & $<0.014^{2}$ & $<0.016^{2}$ & $<0.018^{2}$ \\
\hline $10-\mathrm{c}$ & n.d. & n.d. & n.d. & $<0.018^{2}$ \\
\hline $11-\mathrm{c}$ & n.d. & n.d. & n.d. & $<0.018^{2}$ \\
\hline $12-\mathrm{c}$ & n.d. & $0.200 \pm 0.050$ & $<0.016^{2}$ & $<0.018^{2}$ \\
\hline $13-\mathrm{c}$ & n.d. & n.d. & n.d. & n.d. \\
\hline $14-\mathrm{c}$ & n.d. & $<0.014^{2}$ & $<0.016^{2}$ & $0.058 \pm 0.005$ \\
\hline $15-\mathrm{c}$ & n.d. & $0.018 \pm 0.001$ & $<0.016^{2}$ & $<0.018^{2}$ \\
\hline $16-\mathrm{c}$ & n.d. & n.d. & n.d. & n.d. \\
\hline 17-po & n.d. & n.d. & n.d. & $0.035 \pm 0.006$ \\
\hline 18-po & n.d. & n.d. & n.d. & n.d. \\
\hline $19-\mathrm{po}^{3}$ & n.d. & $0.043 \pm 0.015$ & $0.023 \pm 0.003$ & $0.082 \pm 0.029$ \\
\hline $20-$ po $^{3}$ & $<0.022^{2}$ & $0.171 \pm 0.004$ & $0.048 \pm 0.001$ & $0.289 \pm 0.041$ \\
\hline $8-c^{4}$ & n.d. & n.d. & n.d. & $0.035 \pm 0.001$ \\
\hline $10-c^{4}$ & n.d. & $0.019 \pm 0.003$ & n.d. & $0.024 \pm 0.001$ \\
\hline $11-c^{4}$ & n.d. & n.d. & n.d. & $0.019 \pm 0.002$ \\
\hline $\mathrm{SML}^{5}$ & $\begin{array}{c}\text { Non } \\
\text { detectable }\end{array}$ & $0.3^{6}$ & $0.3^{6}$ & 1.5 \\
\hline
\end{tabular}

*Results for four replicates, with triplicate injections; ${ }^{1}$ n.d. $=$ non detected ( $<$ LOD = Limit of detection: $0.007 \mathrm{mg} \mathrm{kg}^{-1}$ (DIPN), $0.005 \mathrm{mg} \mathrm{kg}^{-1}$ (DIBP and DBP) and $0.006 \mathrm{mg} \mathrm{kg}^{-1}$ (DEHP); ${ }^{2} \mathrm{LOQ}$ : Limit of quantification; ${ }^{3}$ Contact conditions: $50^{\circ} \mathrm{C} / 15 \mathrm{~min}+$ $20^{\circ} \mathrm{C} / 30 \mathrm{~min}$; BBP migration was also detected; ${ }^{4}$ Including printed surface; ${ }^{5}$ Specific migration limits established in Resolution RDC No. 88/16; ${ }^{6}$ The sum of the specific migration of these phthalates shall not exceed $0.3 \mathrm{mg} \mathrm{kg}^{-1}$.

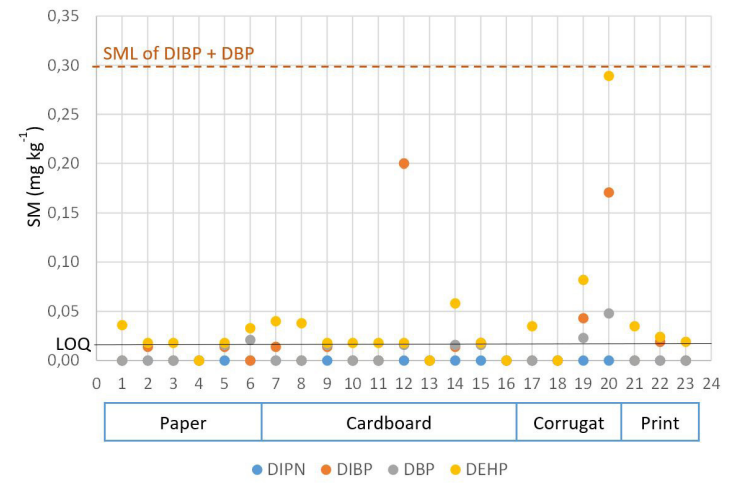

Figure 1. Migration of phthalates and DIPN from cellulose packages evaluated. (Numbers 21-23 correspond to samples 8,10 and 11 , including printed surface). 
Regarding the contaminants, the most harmful phthalate migrated was DIBP since its TDI $\left(0.01 \mathrm{mg} \mathrm{kg}^{-1}\right.$ bw per day) is lower than TDI of DEHP $\left(0.05 \mathrm{mg} \mathrm{kg}^{-1} \mathrm{bw}\right.$ per day) and it showed the highest migration among the samples 1 to 18 evaluated at room temperature. On the other hand, at high temperature (samples 19 and 20), DEHP was the phthalate of major concern regarding migration. Fortunately, the migrated amounts are below the SML of these phthalates.

Samples 19 and 20 are primary packages of takeaway boxes of pizza, a type of food widely consumed in Brazil. Therefore, an estimation of intake of phthalates was made. Estimating the average consumption of 2 slices of pizza $\left(120 \mathrm{~g} \mathrm{slice}^{-1}\right)$ per person with a body weight of $60 \mathrm{~kg}$ and the migration values of phthalates from sample 20 (worst case), the following values of intake of phthalates were obtained: $0.68 \mu \mathrm{g}$ DIBP kg-1 bw, $0.19 \mu \mathrm{g} \mathrm{DBP} \mathrm{kg}^{-1}$ bw and $1.16 \mu \mathrm{g}$ DEHP kg ${ }^{-1}$ bw. These values are much lower than the TDI of the phthalates studied ( $7 \%$ of the TDI of DIBP and $2 \%$ of the TDI of DBP and DEHP). Therefore, even if these phthalates are ingested from other foods along the day, the TDI will probably not be exceeded.

Paper packages (samples 1 to 6 and 16 to 20) are the most critical among the packages evaluated since they are used as primary packaging and therefore, they come into direct contact with foodstuff. Nevertheless, all the migrated amounts are below the SML established (Table 3).

Four samples stood out among the 20 samples evaluated, which are samples 12, 14, 19 and 20 (Figure 1). Samples 12 and 14 are cardboard packages with post-consumer recycled PCR fibers in their formulations, i.e. 5\% PCR (sample 12) and 30\% PCR (sample 14). Although sample 14 had a higher amount of PCR fibers, it showed lower migration of phthalates than sample 12, indicating a lower degree of contamination of sample 14, suggesting that the control of paper recycling of sample 14 is better than sample 12. It is worth highlighting that different manufacturers produced these samples. Corroborating this statement, sample 15 also with 30\% PCR fibers in its formulation and produced by the same manufacturer of sample 14 in different years (sample 14 - April 2018 and sample 15 - January 2019) showed migration levels at LOQ or lower. These results indicate the importance of good control of the supply chain of post-consumer cellulose fibers used in these packages in order to have low migration levels. Anyway, all these samples met the established migration limits.

The levels of migration of phthalates under contact condition of high temperature (samples 19 and 20) were higher than the levels of long-term storage at room temperature due to the higher temperature, which accelerated the migration process as expected. Migration of DIPN was below the quantification limit and migration of phthalates was up to $0.171 \mathrm{mg} \mathrm{kg}^{-1}$ for DIBP, up to $0.048 \mathrm{mg} \mathrm{kg}^{-1}$ for DBP and up to $0.289 \mathrm{mg} \mathrm{kg}^{-1}$ for DEHP (the highest DEHP migration result among the samples). The larger migration of DIBP in comparison to DBP indicates greater contamination of these samples by DIBP since the migration rate of these substances is similar since their chemical structures are also similar ${ }^{[18]}$. On the other hand, the larger migration of DEHP is probably due to its apolar long linear chain $\left(\mathrm{C}_{6} \mathrm{H}_{6}(\mathrm{C}=\mathrm{OOR})_{2}\right.$, with $\left.\mathrm{R}=\mathrm{CH}_{2} \mathrm{CH}\left(\mathrm{CH}_{2} \mathrm{CH}_{3}\right)\left(\mathrm{CH}_{2}\right)_{3} \mathrm{CH}_{3}\right)$, which reduces its interaction with the polar structure of the cellulosic fibers and promotes its migration.

A comparison between the results of specific migration of the samples with the SML values shown in Table 3 leads to the conclusion that all packages analyzed are in conformance with the specific migration limit of phthalates and DIPN, but one sample (20-op). Therefore, these packages should not expose consumers to significant doses of DEHP, which is a phthalate associated with problems in the reproductive and endocrine systems, even taking into account the most critical situation as the hot filling temperature. Regarding DIBP and DBP, the packages showed SM in accordance with the legislation. In relation to DIPN, for which Resolution RDC No. 88/16 establishes that SM should not be detectable, only one packaging (20-po) did not comply with the legislation, since there was a detectable signal for this compound (migration below the quantification limit). In addition, migration of BBP from the sample 20-op was also observed and this phthalate is not listed as an approved substance in RDC Resolution No. 88/16.

Samples 8-c, 10-c and 11-c were also tested for specific migration of phthalates and DIPN without removing the printed face of the cardboard to assess the possibility of migration of these substances from printing inks, which might occur due to the set-off effect. As shown in Figure 1 (samples 21, 22 and 23, respectively), the results of these tests showed increased migration of DIBP into sample 10-c and of DEHP into samples 10-c and 11-c, indicating that the formulations of the printing ink of these cardboards probably contained DIBP and DEHP. For sample 8-c, there was no increase in migration; therefore probably the printing ink on this cardboard did not contain these phthalates. As the concentration of phthalates that migrated to the food simulant was low (just above LOQ), even if a set-off effect occurred, the amount that possibly migrated would be lower than the SML of these substances.

Therefore, these results indicate that the packages under study are not contaminated by phthalates and DIPN, since all of them met the SML established by Anvisa, except for sample 20-po which showed signs of DIPN when submitted to high temperature, besides migration of BBP (a non-listed substance).

\section{Conclusions}

The GC-FID method adopted in this study enabled the determination of migration of DIPN and phthalates from cellulose packages into fatty food simulant. Twenty cellulose packages used for packing dry foods usually sold in the Brazilian market were evaluated. All packages met the requirements of the legislation regarding overall migration. Taking specific migration into account, 50\% of the cellulose packaging samples showed no migration of DIPN or any phthalate evaluated in this study, while $20 \%$ showed migration of DIBP, $15 \%$ showed migration of DBP and $40 \%$ showed migration of DEHP. Regarding the specific migration limits established by Resolution RDC No. $88 / 16$, only one package was rejected due to detection of migration of DIPN and BBP (a non-listed substance) among the samples of paper, cardboard and corrugated 
paperboard evaluated. The other nineteen packages met the requirements of the legislation regarding specific migration of DIPN, DIBP, DBP and DEHP and therefore should not be a relevant source of contamination of dry foods.

An analysis of migration in printed samples showed that even if the set-off effect occurred, the amount of phthalates migrated would be lower than SML, with no risk of food contamination.

Migration of phthalate in samples with $5 \%$ to $30 \%$ PCR content in their formulations was below the SML values established, enabling their use for food contact (in respect to this requirement). The results showed that the season and the recycling process control affect migration outcomes, so companies need to maintain good control of reverse logistics of cellulose fibers to ensure low migration levels.

\section{Acknowledgments}

This work was supported by the São Paulo Research Foundation (FAPESP) under Grant \#2016/24751-3, and by the National Council of Technological and Scientific Development, Brazil (CNPq/PIBIC) under Grant of fellowships. The authors also wish to thank those who provided packaging samples and Cetea's technical staff for collaborating with the tests.

\section{References}

1. Compromisso Empresarial para Reciclagem - CEMPRE. (2021). Taxas de Reciclagem. Retrieved in 2021, June 22, from http://cempre.org.br/taxas-de-reciclagem.

2. European Directorate for the Quality of Medicines \& HealthCare - EDQM \& Council of Europe (2020). Technical guide on paper and board materials and articles for food contact [Draft]. Strasburg: Department of Biological Standardisation, OMCL Network \& HealthCare (DBO). Retrieved in 2021, February 28, from https:/www.edqm.eu/sites/default/files/medias/fichiers/ Food_contact_materials/food_contact_materials_technical guide_on_paper_board_draft_text_for_consultation.pdf.

3. Zhang, K., Noonan, G. O., \& Begley, T. H. (2008). Determination of 2,6 - diisoproprylnaphthalene (DINP) and n-dibutylphthalate (DBP) in food and paper packaging materials from US marketplaces. Food Additives and Contaminants, 25(11), 1416-1423. http://dx.doi.org/10.1080/02652030802163380. PMid:19680850.

4. Geueke, B., \& Muncke, J. (2018). Substances of very high concern in food contact materials: migration and regulatory background. Packaging Technology \& Science, 31(12), 757769. http://dx.doi.org/10.1002/pts.2288.

5. Geueke, B., Groh, K., \& Muncke, J. (2018). Food packaging in the circular economy: overview of chemical safety aspects for commonly used materials. Journal of Cleaner Production, 193, 491-505. http://dx.doi.org/10.1016/j.jclepro.2018.05.005.

6. Munoz, C., Eicher, A., Biedermann, M., \& Grob, K. (2018). Recycled paperboard with a barrier layer for food contact: set-off during stacking or reeling. Analytical method and preliminary results. Food Additives and Contaminants: Part A, 35(3), 577-582.

7. Vandermarken, T., Boonen, I., Gryspeirt, C., Croes, K., Van Den Houwe, K., Denison, M. S., Gao, Y., Van Hoeck, E., \& Elskens, M. (2019). Assessment of estrogenic compounds in paperboard for dry food packaging with the ERE-CALUX bioassay. Chemosphere, 221, 99-106. http://dx.doi.org/10.1016/j. chemosphere.2018.12.192. PMid:30634153.
8. European Union. Regulation (EC) $n^{\circ} 1935 / 2004$ of the European Parliament and of the Council of 27 October 2004. (2004, November 13). Regulation (EC) $n^{\circ} 1935 / 2004$ of the European Parliament and of the Council of 27 October 2004 on materials and articles intended to come into contact with food and repealing Directives 80/590/EEC and 89/109/EEC, Section L 338. Official Journal of the European Union, Brussels. Retrieved in 2021, February 28, from https://eur-lex.europa. eu/LexUriServ/LexUriServ.do?uri=OJ:L:2004:338:0004:00 17:en:PDF.

9. Silano, V., Barat Baviera, J. M., Bolognesi, C., Chesson, A., Cocconcelli, P. S., Crebelli, R., Gott, D. M., Grob, K., Lampi, E., Mortensen, A., Rivière, G., Steffensen, I. L., Tlustos, C., Van Loveren, H., Vernis, L., Zorn, H., Cravedi, J. P., Fortes, C., Tavares Poças, M. F., Waalkens-Berendsen, I., Wölfle, D., Arcella, D., Cascio, C., Castoldi, A. F., Volk, K., \& Castle, L., and the European Food Safety Authority - EFSA (2019). Panel (EFSA Panel on Food Contact Materials, Enzymes and Processing Aids): scientific opinion on the update of the risk assessment of di-butylphthalate (DBP), butyl-benzyl-phthalate (BBP), bis(2-ethylhexyl)phthalate (DEHP), di-isononylphthalate (DINP) and di-isodecylphthalate (DIDP) for use in food contact materials. EFSA Journal, 17(12), e05838. http://dx.doi. org/10.2903/j.efsa.2019.5838. PMid:32626195.

10. Brasil. Agência Nacional de Vigilância Sanitária - Anvisa. Resolution RDC n 88 from 29 June 2016. (2016, June 30). Approval of technical regulations on cellulosic materials, packages and equipments intended to come into contact with foodstuffs and and makes other provisions, Section 1. Diário Oficial da República Federativa do Brasil, Brasília, DF. Retrieved in 2021, February 28, from https://www. in.gov.br/materia/-/asset_publisher/Kujrw0TZC2Mb/content/ id/23163458/do1-2016-06-30-resolucao-a-rdc-n-88-de-29-dejunho-de-2016-23163247.

11. Magdouli, S., Daghrir, R., Brar, S. K., Drogui, P., \& Tyagi, R. D. (2013). Di-2-ethylhexylphthalate in the aquatic and terrestrial environment: a critical review. Journal of Environmental Management, 127, 36-49. http://dx.doi.org/10.1016/j. jenvman.2013.04.013. PMid:23681404.

12. Sant, K. E., Dolinoy, D. C., Jilek, J. L., Sartor, M. A., \& Harris, C. (2016). Mono-2-ethylhexyl phthalate disrupts neurulation and modifies the embryonic redox environment and gene expression. Reproductive Toxicology, 63, 32-48. http://dx.doi. org/10.1016/j.reprotox.2016.03.042. PMid:27167697.

13. Muncke, J., Andersson, A.-M., Backhaus, T., Boucher, J. M., Carney Almroth, B., Castillo Castillo, A., Chevrier, J., Demeneix, B. A., Emmanuel, J. A., Fini, J.-B., Gee, D., Geueke, B., Groh, K., Heindel, J. J., Houlihan, J., Kassotis, C. D., Kwiatkowski, C. F., Lefferts, L. Y., Maffini, M. V., Martin, O. V., Myers, J. P., Nadal, A., Nerin, C., Pelch, K. E., Fernández, S. R., Sargis, R. M., Soto, A. M., Trasande, L., Vandenberg, L. N., Wagner, M., Wu, C., Zoeller, R. T., \& Scheringer, M (2020). Impacts of food contact chemicals on human health: a consensus statement. Environmental Health, 19(1), 25. http://dx.doi. org/10.1186/s12940-020-0572-5. PMid:32122363.

14. Poças, M. F. F., \& Hoog, T. (2007). Exposure assessment of chemicals from packaging materials in foods: a review. Trends in Food Science \& Technology, 18(4), 219-230. http://dx.doi. org/10.1016/j.tifs.2006.12.008.

15. Nerín, C., Cacho, J., \& Gancedo, P. (1993). Plasticizers from printing inks in a selection of food packaging and their migration to food. Food Additives and Contaminants, 10(4), 453-460. http://dx.doi.org/10.1080/02652039309374168. PMid:8405584.

16. Asensio, E., Peiro, T., \& Nerín, C. (2019). Determination the set-off migration of ink in cardboard-cups used in coffee 
vending machines. Food and Chemical Toxicology, 130, 61-67. http://dx.doi.org/10.1016/j.fct.2019.05.022. PMid:31102676.

17. Poças, M. F., Oliveira, J. C., Pereira, J. R., Brandsch, R., \& Hogg, T. (2011). Modelling migration from paper into a food simulant. Food Control, 22(2), 303-312. http://dx.doi. org/10.1016/j.foodcont.2010.07.028.

18. Coltro, L., \& Machado, L. G. S. (2020). Migration of phthalates from cellulose packaging into food simulant: assessment of different levels of contaminants. Macromolecular Symposia, 394(1), 2000070. http://dx.doi.org/10.1002/masy.202000070.

19. Graiño, S. G., Sendón, R., Hernández, J. L., \& Quirós, A. R. B. (2018). GC-MS screening analysis for the identification of potential migrants in plastic and paper-based candy wrappers. Polymers, 10(7), 802. http://dx.doi.org/10.3390/polym10070802. PMid:30960727.

20. International Organization for Standardization - ISO. (1993). ISO 4593: plastics - film and sheeting - determination of thickness by mechanical scanning ( 2 p.). Switzerland: ISO publications.

21. Associação Brasileira de Normas Técnicas - ABNT. (2012). NBR ISO 3034:2011. Corrugated fiberboard - Determination of single sheet thickness. $(9$ p.). Rio de Janeiro: ABNT.

22. Associação Brasileira de Normas Técnicas - ABNT. (2000). NBR NM-ISO 536:2000. Paper and board-Determination of grammage. (6 p.). Rio de Janeiro: ABNT.

23. Coltro, L., Pitta, J. B., Costa, P. A., Perez, M. A. F., Araújo, V. A., \& Rodrigues, R. (2014). Migration of conventional and new plasticizers from PVC films into food simulants: a comparative study. Food Control, 44, 118-129. http://dx.doi. org/10.1016/j.foodcont.2014.03.058.

24. Ribani, M., Bottoli, C. B. G., Collins, C. H., Jardim, I. C. S. F., \& Melo, L. F. C. (2004). Validation of chromatographic and electroforetic methods. Quimica Nova, 27(5), 771-780. http://dx.doi.org/10.1590/S0100-40422004000500017.
25. Ribeiro, F. A. L., Ferreira, M. M. C., Morano, S. C., Silva, L. R., \& Schneider, R. P. (2008). Validation spreadsheet: a new tool for estimating the analytical figures of merit for the validation of univariate methods. Quimica Nova, 31(1), 164 171. http://dx.doi.org/10.1590/S0100-40422008000100029.

26. Instituto Nacional de Metrologia, Qualidade e Tecnologia INMETRO. (2018). General Coordination of Accreditation. DOQ-CGCRE-008: guidance on validation of analytical methods (Revision No 07). Rio de Janeiro: INMETRO.

27. Association of Official Analytical Chemists - AOAC. (2013). Official methods Analysis. Appendix K: Guidelines Dietary Supplementsand Botanicals. (32 p.). Gaithersburg: AOAC.

28. Bonini, M., Errani, E., Zerbinati, G., Ferri, E., \& Girotti, S. (2008). Extraction and gas chromatographic evaluation of plasticizers content in food packaging films. Microchemical Journal, 90(1), 31-36. http://dx.doi.org/10.1016/j.microc.2008.03.002.

29. Bueno-Ferrer, C., Jiménez, A., \& Garrigós, M. C. (2010). Migration analysis of epoxidized soybean oil and other plasticizers in commercial lids for food packaging by gas chromatography - mass spectrometry. Food Additives and Contaminants, 27(10), 1469-1477. http://dx.doi.org/10.1080 /19440049.2010.502129. PMid:20635266.

30. Coltro, L., Saron, E. S., Pessoa, T. I., Ferreira, I. A. G., Silva, B. S., Hamdan, M., \& Santos, B. B. (2019). Conformity assessment of cellulosic food packaging in relation to phthalates, 2,6-diisopropylnaphthalene and metals. In Proceedings of the 4th International Conference on Food and Biosystems Engineering - FABE (pp. 50-57). Crete Island, Greece: University of Thessaly.

Received: Feb. 28, 2021

Revised: May 18, 2021

Accepted: June 07, 2021 